AN EXERCISE IN EARLY MODERN BRANDING

Dr Ruth Herman

University of Hertfordshire

Business School

Hertford Campus

Mangrove Road

Hertford

Herts. SG13 8QF

Tel: 01707285495

Fax: 01707285410

Email: r.a.1.herman@herts.ac.uk 


\section{An Exercise in Early Modern Branding}

This article examines the marketing of an author through the integration of their persona into their text to form a brand that can then be purchased by the consuming reader with confidence. Thus a reader chooses a book by a writer known for a particular genre following the same instincts that might prompt them to choose a successful brand. The example used is an early modern woman writer, who developed a genre of scandal fiction that became synonymous with her. The article contextualises the writer giving some indication of the prevalent market conditions and her motivation in differentiating herself from her competitors.

\section{Dr Ruth Herman}

Dr Ruth Herman is a senior lecturer in marketing at the University of Hertfordshire. Her commercial background is in public relations and small business management. She has a BA in English Literature with Historical Studies and an MA in Marketing and Organisational Studies. Her doctoral thesis was on early modern propaganda and featured Delarivier Manley. The thesis, The Business of a Woman, is now in press with the University of Delaware Press and is due for publication in 2003. Dr Herman has published on early modern political literature.

Having recently moved from a humanities teaching post to the Business School, Dr Herman is interested in ways of fusing humanities and business research areas. This is particularly useful when exploring the marketing of creativity, particularly in the field of publishing. A natural extension of this area is that the use of language to persuade, sell or promote products and ideas. Dr Herman is a member of the Chartered Institute of Marketing and the Institute of Public Relations. 


\section{DELARIVIER MANLEY: AN EXERCISE IN EARLY MODERN BRANDING}

\section{Introduction}

There is an ever-increasing interest in the origins of modern marketing practices. While marketers identify the origins of the 'construct' of marketing (Enright 2002) we now accept that consumers and producers have been involving themselves in the practice, that is the sale and promotion of goods for time immemorial. Somewhat newer to marketing theory is the notion of branding, although again it has been argued that 'brands' have been a marketing tool for at least 300 years (Koehn 2001). This article examines branding from a historical perspective after a very brief exploration of its modern meaning. It looks at efforts of an early eighteenth century writer, Delarivier Manley (1667?-1724) to fashion a brand from an integration of her own carefully constructed persona with her published work. Although it could be argued that the use of the term 'brand' for this is anachronistic, we argue that it is a useful term for Manley's efforts to complement her textual product with her persona, using the resulting 'celebrated' status to sell the books. Through this author's use of her personality as a marketing tool, we examine the relationship between a creative writer and their work, and the strategies available for the successful marketing of the resulting works.

The article gives an overview of the market within which Manley worked and considers how she differentiated herself and her product from her competitors. The article also suggests that while Manley clearly worked within a far less sophisticated marketing environment than pertains today, she understood the fundamental linkage between a writer and their work which binds them together as a product. 


\section{Methodology}

The research has been conducted through extensive archival and historical research. There has been wide-ranging reading of manuscripts and primary texts, written and published by Manley and her contemporaries during and after her lifetime. A careful analysis of the commercial and literary milieu within which she worked has also been undertaken, all of which allows us to understand more thoroughly the conditions under which texts were sold and promoted in the early modern period. The results of the archival and historical research have then been matched with more recent discussions on aspects of marketing and branding. As a result of this the reader will see references to modern research as explanatory to early modern (specifically eighteenth century) marketing practices. While this may at first seem an anachronistic yoking, we would argue that it is justifiable in that it sheds light both on the origins of practices in use today and on the sophistication of practices in use then, thus providing a useful way to gauge their development over the ensuing years.

\section{The Brand}

Branding is a central theme to this article and a topic that remains high on the research agenda, as it has been for several decades (Aaker, 1991). It seems clear that branding is a fundamental marketing requirement where the consumer has to make choices between similar products. Therefore the rationale behind brand creation is to establish a distinct and differentiating identity for a product for the consumer, (Betts1994) or as one researcher has succinctly put it, 'Brand names that have the ability to rise above the clutter get noticed' (Kohli 1997). Specifically for our purpose, it has been noted that consumers particularly differentiate between brands where image rather than physical characteristics are emphasised. (de Chernatony 1996) 
Facilitating this choice are the tangible and intangible elements to a brand, (de Chernatony and Riley 1997) although when considering the branding of a creative product (such as fiction) there will be an intangible differentiation that rests entirely upon the audience's emotional response. Therefore, when looking for similar branding theories, we might find resonances in the branding of services (Grace and O'Cass 2002) and even politics (Lock and Harris 1996, Smith 2001), since in both cases the consumer's attitude towards the brand's intangible elements is fundamental to success. A definitive survey of all the research about branding is beyond the scope of this article (even if it were feasible) but for a thorough exposition of the wide ranging work done, we would direct the reader to Wood (2000) who shows clearly that the road to a more sophisticated discussion of branding and the importance of behavioural and attitudinal issues within the debate has been a long one.

\section{The origins of branding}

As we suggested earlier, however, branding as a concept is older than the modern theory. Even the word would have been recognised by the Vikings who used 'brandr' (Keller 1998) to signify the burning of the owner's mark on livestock. It takes on a more recognisable meaning in 1587 when it meant a stamp of quality. (Harvard Business Review 1999; Koehn 2001) This begins to tie up with more modern notions in 1602 when it was used to suggest an indelible stamp on the memory, perhaps unconsciously prompted by the iconic Tudor representations of the monarch (King 1990) presented to their subjects as a 'brand'. We could argue that all these definitions merged in 1827 when the word first denoted a trademark. ${ }^{1}$ One hundred and fifty years later Borden (1964) still saw branding in terms of trademarks as one element of the marketing mix whose main importance was the enabling of

\footnotetext{
${ }^{1}$ These are Oxford English Dictionary definitions.
} 
differentiation between 'individualised' or 'family' brands. By 1979 the brand had become an entity in its own right (Day et al 1979) with expressed concerns about brand-switching between frequently purchased goods.

\section{The Brand's Origins in the Eighteenth Century}

In this article we wish to look at the 'brand' as it stood at the birth of the consumer society, a period which is increasingly appreciated as key to the origins of marketing as a recognised practice. (McKendrick 1982, De Vries 1994, Berger 1980, Jones 1996, Tann 1977, Mathias 1979) Daniel Defoe, for instance, in his early management guide, The Complete English Tradesman understood such concepts as brand loyalty. His comment that 'customers ... are gained and preserved by good usage, good pennyworths, good wares, and good choice,' (Defoe, 1726,1987) is a close forerunner to the more recent, 'Managers must constantly work hard on maintaining reputation since it appears a firm is only as good as its last transaction or two.' (Herbig and Milewicz 1995)

This reputation was particularly relevant in the small world of early modern Britain when 'branding' (in the most modern sense) was often located in the individual. To put this proto-branding into perspective we need only look as far as the 'doctor-turned-dentist and seller of medicine' who advertised himself and his purple painted pony, or the ginger bread seller who differentiated himself through his fake court dress. (McKendrick 1982)

The period also offered traders a ready market and a 'dependence on acquisition'. (Stearns 1997) In accordance with the well established relationship between consumption and self, (Belk 1988) the eighteenth century consumer used shopping as an opportunity for 'personal expression through acquisition', (Stearns 
1997) just as the modern consumer chooses brands on the basis of their 'symbolic' rather than 'functional' qualities. (Jamal and Goode 2001).

Eighteenth century marketers used this 'symbolism' to promote their products recognising, like later marketers, the value of celebrity endorsement. They, too, understood that 'pairing products with very different celebrities ... [affects] subjects' images of those products' (Till 1998) and that there is therefore a real benefit in coupling famous people with brands. (Gwinner 1997, Dickenson, 2001). Manufacturers such as Josiah Wedgwood courted the aristocracy as patrons, thereby encouraging the emulating 'lesser sort' to buy his (Duchess of) Devonshire flowerpots and his Queensware (McKendrick 1982, Koehn 2001). The association with the 'ton' emphasised the elegance of the product, prompting its purchase (Plummer1986) while its aristocratic associations reinforced its consumer's self-image (Elliott and Wattanasuran 1998; Nia and Zaichowsky 2000). When it came to endowing a brand with personality, (Aaker 1996, Aaker 1997) Wedgwood seems to have known instinctively that he had to 'breathe life' (Meenaghan 1995) into his inanimate products, which he did by associating them with the cream of society.

\section{The Brand and the Creative Writer}

Following Wedgwood's example, marketers still promote brands through 'a personal relationship' with celebrities, such as Richard Branson and Virgin. While Meenaghan (1995) may argue, however reductively, that Kotler's definition of the brand as a 'name, term, sign, symbol or design' falls short of describing the 'magnetic' relationship between a conventional brand and its consumers, we must acknowledge that it is even more difficult to find the words to evaluate a brand whose appeal rests largely on the consumer's intangible emotional reaction, as in the case of art, fashion or performance. There are certainly examples in the art world of the 'self-publicising' 
artist/marketer (Fillis 2002) whom one might regard as a brand. It is, we would argue, even more difficult to analyse the branding of creative writing, where the tangible product is a mere collection of words rather than a instantly recognisable painting or sculpture. In both instances the artist/writer is intrinsic to the product and their promotion of their own work is in effect self-branding, so that they and their product are inseparable into discrete parts.

\section{Print as Product}

In this discussion of the creative brand, print is indeed the least tangible, but the most purchasable. Unlike much fine art, replication and dissemination is its declared goal. Even the rarest first edition was once published in multiple copies, however small the print run, and was intended to reach multiple consumers. We would maintain that the ultimate aim of those who publish (as opposed to those who simply write) is to place their work in front of readers, however selectively targeted, making marketing a key factor in the dissemination of their ideas. The production process is unique, however. Unlike other products, and even taking the editing process into account, it is rarely a team effort. Placing someone else's hand on the same pen and asking them to write about the same subject is likely to produce an entirely different product. The reader's interest in authorial participation in the creative process also presents a marketing opportunity. While Barthes (1977) regrets this as the 'explanation' of a work through 'the man or woman who produced it' he also acknowledges that our thoughts are often 'tyrannically centred on the author, his person, his life, his tastes, his passions'. As long as the consumer is fascinated by these 'passions', the skilful presentation of these assets, even their exaggeration or fabrication, presents the marketer of creative writing with an invaluable sales aid. The real writer may, as Joyce (1992) suggests, remain invisible 'within or behind or beyond or above' his or 
her handiwork, but the reader will inevitably want a substitute, either accepting a constructed personality provided by a publicity machine, or providing one for themselves by asking 'What sort of person would write this sort of book'? The author is thus part of the product. That these reader acceptances (or fantasies) facilitate commercially viable authorship has been acknowledged since the seventeenth century. (Turner 1992, Hammond 1997)

\section{The Individual and the Brand}

Since we are concerning ourselves with the origins of this complex marketing phenomenon, the author-as-product, we must also acknowledge that when analysing the early modern publishing industry we are inevitably reading modern theory back into the informal and intuitive activities undertaken at a time when consumerism was in its infancy. When considering an early modern writer's marketing strategies, is it appropriate to compare her efforts with Thompson's (2000) description of Elvis fashioning 'himself into a living work of art', or Street's (1993) argument that popular appreciation of culture is 'constituted by collective and individual memories of past experiences'? For we are discussing a period when, for the most part, consumers of texts had very few past purchasing experiences to remember. (Labio 1998, Weatherill 1988) Indeed, we should also bear in mind that Street and Thompson both refer to the modern music industry, where producers and consumers communicate in a developed marketing language. Clearly in our subject's, Manley's, case this language had not yet been articulated. Having said this, prior to Manley taking up her pen, there had been at least one role model for her to look to for marketing inspiration. She was certainly aware of the reputation and the work of the first professional woman author, Aphra Behn, whose 'immoral' life (Gildon 1696) could have provided motivation for 
Manley's 'use of scandal' as a branding strategy (Schroeder 2000) facilitating her entry into the marketplace at a propitious moment.

\section{The Commercial Context}

It was indeed an appropriate time to begin writing for money. (Myers and Harris 1981) In the absence of patronage or sponsorship, commercial viability for a writer depends on a sufficiency of reading consumers to buy books. In the eighteenth century, while no really accurate figures are available it is generally agreed that rapidly rising levels of literacy and increasing leisure among the middling ranks made publishing an attractive proposition. (Rivers 1982) The novel as we know it barely existed but poetry, play-texts and religious tracts abounded while the turbulent political times fuelled an infant news industry. Women's magazines were born. (Sutherland 1934-5, Black 1987) Sensational gossip sold extremely well. Readers could wonder at women giving birth to live rabbits or about lesbianism among the Queen's favourites (Rival Dutchess 1708). The choice of reading material was eclectic, from a royal recipe book (Lamb 1710) to lurid titles such as The Nun in her Smock or A Treatise on the Use of Flogging (Strauss, 1925). With the removal of government control over printed matter in 1696 the industry was also becoming more commercially aware. The introduction of copyright in 1710 (Feather 1980) also paved the way for new business strategies (Myers and Harris, 1981).

\section{Advertising}

As the publishing industry developed so did advertising, providing new marketing opportunities. (Porter 2000) The readership of periodicals increased and producers of everything from quack cures, to tea to dressing gowns to real estate were conscious of their marketing potential (Bruttini 1982; Doherty 1992, Berg 1999, Porter 2001). Even the urbane Joseph Addison considered the 'advertisement' interesting enough to 
devote an entire issue of The Tatler to it. (14 September 1710) Advertising columns also provided excellent opportunities for publishers (who usually handled both periodical and book printing) to advertise their own titles, thereby increasing their own profits. (Examiner, 1710-14)

\section{Delarivier Manley and The New Atalantis genre}

Manley's ground-breaking work of fiction, The New Atalantis (1709) maintained a permanent position in The Examiner's advertising columns for four years. Although no actual figures are available we can judge that the sales of the book were healthy since it went through nine editions in the first twenty years and was translated into French and German. The book incorporated a loose fictional account of the sexual exploits of major political figures hidden under barely disguised names with the government of the day and their sexual peccadilloes as the main victims. Its original purpose was to embarrass the Whigs who formed the government. In the turbulent political atmosphere (Holmes 1967) in which it was first published this proved an irresistible feature. Not surprisingly the powerful victims thought this new literary development rather too seditious for comfort and Manley was arrested and thrown

into prison, although she was soon released with no charge. ${ }^{2}$ The resulting popularity of this text (no doubt helped by the author's arrest) made the title synonymous with the genre, and with Manley, and as such the book reappears throughout literature for the next fifty years, while she becomes the focus for comments on it. (Duncombe 1981)

Most of the writers in this volatile environment have now been forgotten and quite a few political writers were never known by name, the laws of seditious libel sometimes requiring the forfeit of liberty rather than money, (Kropf 1974-75) and 
even writers such as Daniel Defoe famously found himself in the stocks for a literary transgression. It was therefore remarkably brave of Manley to implement a marketing strategy that distinguished her so vividly from her more wary colleagues. Indeed, as her brand evolved, this boldness was signalled as one of its most recognisable attributes as she continually reiterated how she had been prepared to use her pen against corrupt statesmen (Manley 1714). Not all writers hid behind anonymity, particularly if they did not write anything particularly contentious. Dramatists affixed their name to their play texts when they sold the manuscript. Women dramatists, such as Susanna Centlivre, Mary Pix and Catherine Trotter relied on this funding, (Cotton 1980) although unlike Manley they did not invest their own life stories into their texts. Manley's willing identification with her writing and particularly the new and dangerous Atalantis genre is at least partly due to her willingness to be associated with and within the text so that the two became inseparable. To appreciate fully the care with which Manley built what we might call her authorial brand we must compare her with her contemporaries. Manley's fellow male and female writers, almost without exception, declined from introducing their own identity into their popular work, and certainly not into its marketing. (Gallagher 1994) Trotter, for instance, wrote light fiction and plays during her early years. When she married a clergyman she disowned some of these earlier texts, preferring to be known for her later philosophical writings that gave her prestige but not income. (Kelley 2002) Manley was therefore unusual in appreciating the commercial capital to be made from binding her name, her life story, her reputation and her 'Atalantis' books into one identifiable entity that might be described as a proto-brand. Manley nurtured the link between herself and her work, often referring to herself as 'the author of Atalantis',

\footnotetext{
${ }^{2}$ It is unfortunate there is little evidence aside from what Manley chooses to reveal in her
} 
reinforcing this combination, becoming a named producer of an immediately identifiable, and profitable, genre.

The potential of this new writing style was also evident to her contemporaries and Manley fully understood the need to protect her name from imitators. Modern researchers might have called her a 'tough competitor' (Herbig and Milewicz 1995), when she reacted strongly to one fake text and warned the public that the "Author of $[\ldots]$ the Atalantis, [...] having never seen this Book, nor knowing any thing of the Contents, will not be answerable for whatever may be display'd therein.'(Examiner, 1714) She was equally concerned with the quality of the presentation of her own work, and complained when her own publisher issued work without her permission, that the pirate publication was 'ridiculously mangled, and very uncorrectly Reprinted by the Management of a Grubstreet Pen, without the Consent or Knowledge of the Author of the Atalantis' (Examiner1711).

\section{The need for differentiation}

With the expansion of the publishing industry, authorship became increasingly commodified. A seemingly endless supply of writers meant that eighteenth century writers were often indistinguishable hacks. (Speck 1998, Tompkins 1969)

Booksellers kept them busy churning out material for an eager market while the few best sellers provided easy templates for less imaginative writers. (Treadwell 1980) Early eighteenth century legislation did nothing to protect the writer. The first copyright law was passed in 1710 but ownership of the text passed into the hands of the booksellers after a one-off payment with the booksellers retaining the ensuing copyright and any subsequent profit. Few authors even bothered to register their name against new publications as copyright was traded between booksellers with no 
further recourse to the writer. Manley's marketing efforts were therefore partly driven by need to differentiate herself from her imitators and she laid legal claim to the New Atalantis as soon it became possible in order to establish her stake in it. (Stationers Company 1710)

This was not surprising since she had always been determined to put her name to her texts for at least thirteen years before the copyright laws were passed. Even her first book, published by a 'friend' 'without [her] Leave' probably acted as a publicity device for her first two plays of the same year (Manley 1696) It would have helped to establish her name at a time when the theatre fairly bristled with "new female playwrights'. (Hobby 1988) She no doubt calculated that putting her name before the public would boost 'third night' performance receipts, when the takings would pass to the author as payment. In addition, the volume introduced her name into another market, that of prose writing, when the theatre's popularity may have been waning. (Labio 1998)

In this instance, as she did later, she showed a talent for publicity far in advance of the other women playwrights of the same year who showed no such initiative. Four years later she rounded up several women poets to contribute to a slim volume of poetry commemorating the death of the poet laureate John Dryden (Manley 1700). Significantly, she was the only one who did not choose to use a pseudonym. If we are seeking early examples of the construction of a brand 'personality' it is worthwhile reading Manley's early writings. Read in conjunction with later selfpublicity, they show her steadily introducing the attributes that remained core to her 'brand'. These included her intellectual superiority to other women, her generosity and, paradoxically, a portrait of herself as a victim of the 'Injustice of Fortune,' 
(Manley1696) features which are apparent throughout her work, making them intrinsic to a 'brand personality' constant throughout her career.

\section{Manley and the New Atalantis as a Brand}

David Aaker's (1996) description of the 'Brand as Person perspective' (or, if we may put it, 'Person as Brand') as being 'richer and more interesting than one based on product attributes' is relevant. We have argued through her reiteration of core attributes, Manley made herself immediately identifiable and available for an empathetic relationship with the consumer. If a consumer finds self-expression through the purchase of a specific brand they also build a relationship with the product. (Fournier 1998) This same relationship is key to the building of loyal readership. Reader response theory demonstrates that reading is a two-way process with the reader's intrinsic involvement in the text. (Freund 1987) In the intimate act of reading, the choice of material is a form of self-expression demanding a considerable personal investment of time and emotion. Manley understood this, including the autobiographical details in the Atalantis novels to amplify the reader's identification with her, so that she became integral with the text rather than the mere 'producer'. Thus when a reader bought her novel, s/he bought an experience, which included a relationship with Manley herself. Given the success of the rapport she developed with her readers it was not surprising that the four New Atalantis volumes were a success.

Manley's self-promotion was a marketing strategy developed through a deliberate fusion of writer and text. The elastic supply of literature made her differentiation within the ever-expanding market essential. The number of Atalantis derivatives indicated that she achieved this. The success of Manley's brand is demonstrated through her readers' perception that she remained the supreme exponent 
of her brand which de Chernatony and McDonald argue is essential. (1994) While retrospective market research is not easy to obtain, extant letters from eager readers desperate for the next volume testify to this. (Halsband 1965) There were even some people who claimed to have no interest in reading the texts and yet still noted Manley's role in their writing. (Bridges 1709) If awareness is key to brand success, this widespread recognition is significant. Even after her death critics regarded Manley and the Atalantis genre as inseparable. (Duncombe 1981)

\section{Constructing the Manley Image}

We will now examine how Manley the Atalantis writer consciously constructed an image of herself as a marketable product. The novels with her name on the title page were the physical evidence guaranteeing to the consuming reader they were reading the genuine article, and not a copy. Corroborating this she placed the image of herself within the text as a woman 'who knows how to live' (Manley 1714) and by sharing her own chequered past with her readers she gave her scandal fiction its credibility. She featured herself in her texts so that she became an easily recognisable participating character, selling the product through her own presence within it. She went so far in her commodification of herself that in her fictionalised autobiography she virtually reduced herself to an assembly of components: 'admirably coloured lips', 'small and even' teeth, 'publickly celebrated' hands and arms, 'small and pretty' feet, 'sweet' breath, and a 'neck and breasts' with an 'established reputation' for beauty and colour. (Manley 1714)

In the absence of a cover photograph or portrait this gave the reader an opportunity to engage with a real person. The fact that Jonathan Swift described her as being in reality 'very fat and very homely' demonstrates her creation of an appropriate image which was distinct from her own physical identity. 


\section{The components of the 'personal' brand}

As well as this physical description the autobiographical details were equally specific to Manley. In addition to her much discussed arrest for seditious libel, (Luttrell 1857, Halsband 1965) Manley’s colourful personal history became integral to her work, which from the beginning traded on its sensational and sexually provocative nature. (Manley b 1696, 1707) In the first volume of the New Atalantis the sexuality becomes self-referential by including herself as a woman heavily pregnant by her lover offering advice to a previous partner. Included in her Atalantis texts were details of her marriage to, and subsequent abandonment by, her bigamist cousin, a prominent Tory MP, and his extra-marital affairs. Her brief stint as the gaming companion to one of the most notorious royal whores of the period is included, as is a bitter attack on the fellow poet whose evidence caused her to be charged with fraud. Throughout her work she conducted a public feud with her former lover the acclaimed political essayist, Richard Steele. She also revealed to her reader her affair with one of the most dishonest prison governors England has ever known. Her texts and her reputation thus merged outside of her novels with one contemporary referring to her as a 'Town Lady'. (Bridges 1709)

Readers familiar with her work may even have recognised a publicity campaign that started prior to publishing the New Atalantis, (Herman 2001) suggesting that she knew that her public would buy the woman as much as the writing. By laying her intimate details in front of the reader and skilfully mixing creativity and sensationalism she consolidated the 'personality' that radically distinguished her from her competitors, deliberately building a marketable persona, which could be part of her published work and act as an advertisement for it. As she says in her autobiography, she had 'carried the passion [of love] farther than could be readily 
conceived' and 'it would have been a fault in her, not to have been faulty' (Manley 1714). Since her serious political journalism, as distinct from her scandal fiction, was published anonymously, it seems equally clear that she too understood that the Atalantis brand needed to remain separate from the polemic.

With the benefit of hindsight we would suggest that it was the unique combination of an avid reading public in conjunction with ability to complement a persona with a writing style engendered the consumer confidence essential to successful brand creation. (Dickenson 2001) Her writing was certainly admired (Gildon 1702, Langbaine 1712) and the peculiar combination of risqué writing and peer admiration made her the queen of her Atalantian genre. (Morgan 1986, Todd 1988, Herman 2003)

\section{Other Writers' use of the Brand}

Manley's image building was an effective strategy and her name on the front page was a guarantee that the contents would be satisfactory, in the same way as a brand name provides consumer confidence. Indeed, the equity of Manley's Atalantis brand was high enough that her friends affixed her name to texts. (Arbuthnot 1976). Writers who did not know her at all dedicated their books to her in the hope that this equity would rub off onto them. As one mediocre writer said in a preface to yet another derivative novel, 'Your name prefixed to anything of love, who have carried that passion to the most elegant heighth in your own writings, is enough to protect any author who attempts to follow in that mysterious path.'(Hearne 1718). Some writers appropriated the Atalantis title to give their own books credibility. Even Daniel Defoe borrowed the name. But, as Mats Urde has pointed out, when discussing rather more conventional branding, 'brand identity is experienced by customers as valuable and unique and becomes difficult for competitors to imitate.' (Urde 1999) Given this, 
it is significant that no other author managed to overtake her in this field of writing and Manley remained the mistress of her particular mixture of political comment and scandal. The extent to which her competitors attempted, unsuccessfully, to imitate and capitalise upon the new genre that Manley created and dominated equally demonstrates the strength of the brand she had created for herself. (Nia and Zaichowsky 2000)

\section{A brand or a name?}

We can see from all this that Manley was more than competent in promoting herself and her work as one. We would suggest this does have timeless implications for marketing 'celebrity' creative writing, because the work and the name were so integrated, although disentangling the retrospective implications of this for a straightforward theoretical model is not easy.

What modern parallels can we draw? We cannot say that she 'endorsed' her writing, since that would have involved her participation in the promotion of something extrinsic to herself (Till 1998) and as we have suggested a text and its writer are intrinsically bound together by the creative process. There is perhaps an argument that she lent her texts 'cachet' or credibility. This certainly would be the case for latter day celebrity autobiographies, not bought for their intrinsic literary value but because they have a 'name' attached. For Manley too, later texts may have been popular because of their association with her. Indeed, she briefly ran her own crude market research on this by having a play produced anonymously to see whether withholding her name affected its reception. (Defoe 1741) As the play was a success it is difficult to form any conclusions, although we would argue that since the play was not 'Atalantean' (but by the 'Atalantean' author) this might be regarded as an experiment in brand extension. (Chapman, Aylesworth 1999) This concept of 
'extension' can also explain the 'author of Atalantis' being named on the wildly successful John Bull pamphlets published in 1712 presumably with her permission since no objections were made. Whether this indicated some involvement in them (Herman 2003) or not, it certainly suggests that she was known as the 'most celebrated contemporary theorist and practitioner' of her genre. (Eriksson and Bowyer)

\section{Conclusion}

From the foregoing, we are confident that the early modern scandal fiction writer Delarivier Manley positioned herself in her own market-place, finding and protecting a niche for her carefully combined literary and personal persona, deliberately writing to attract readers with sufficient leisure to spend time on the written word. In some instances the targeting is surprisingly explicit knowing that she must appeal to the Tory segment of the middling and upper classes (including women) for her readership.

If we can extrapolate on this, we would suggest that Manley's strategies are still relevant to the ways in which creative writers disseminate their texts, and that these have not changed fundamentally over several hundred years. The world has become more complex since Manley's day and communications are quicker. Consumers have more choice, but creativity is still a marketable product and often the marketability is based on the creator as much as on the work itself. When this happens, and the artist and their work become synonymous, a brand is formed which promotes loyalty in the consumer, particularly in those areas which encourage repeat purchases, such as works of fiction. Unfortunately, we still cannot provide the formula for a best seller. But the work done does suggest that the integration of writer and text is a contributing factor giving the consumer the necessary confidence to purchase new texts from the 
writer and engendering loyalty to the author's 'brand'. While in this instance we have used an early modern writer as our example, it would be a valid exercise to apply these same criteria to modern best selling authors to see if the principles had changed dramatically, even though the marketing techniques may have become more sophisticated.

5382 words

\section{References}

Aaker, David A. (1996), Building Strong Brands. New York: Free Press.

---- (1991), Managing Brand Equity. New York: Free Press.

Aaker, Jennifer L. (1997), "Dimensions of brand personality”, Journal of Marketing Research, Vol. 34, No. 3.

Belk, Russell (1988), "Possessions and the Extended Self", Journal of Consumer Research, Vol. 15, 139-168

Berg, Maxine (1999), "Eighteenth Century England" in Consumers and Luxury:

Consumer Culture I Europe 1650-1850. Maxine and Helen Clifford Manchester: Manchester University Press.

Berger, Ronald M., "The Development of Retail Trade in Provincial England, ca. 1550-1700", The Journal of Economic History, Vol. 40, No. 1, pp. 123-128.

Betts, Peter (1994), "Brand Development: Commodity Markets and ManufacturerRetailer Relationships", Marketing Intelligence \& Planning, Vol. 12, No. 9, pp.18-23 Black, Jeremy (1987), The English Press in the Eighteenth Century. London: Croom Helm

Boccalini, Tragario (1794), Advertisements From Parnassus, 2 vols, London: Richard Smith. 
Borden, Neil (1964), “The Concept of the Marketing Mix”, Journal of Advertising Research (June), pp. 2-7

Bower, Alan W., and Robert A. Erickson, (1976), John Arbuthnot, The History of John Bull. Oxford: Clarendon Press.

Butler, Marilyn (1981), Romantics, Rebels and Reactionaries. Oxford: Oxford University Press.

Chapman, Kenneth J. and Andrew Aylesworth (1999) "Riding the coat-tails of a positive review: rave reviews and attitude transfer", Journal of Consumer Marketing. Vol. 16, No. 5, pp. 418-440.

Chernatony Leslie de and Malcolm MacDonald (1994), Creating Powerful Brands. Oxford: Heinemann.

de Chernatony Leslie (1996) "Integrated brand building using brand taxonomies", Marketing Intelligence \& Planning, Vol. 14 No. 71996 pp. 40-45

de Chernatony, Leslie and Francesca Dall'Olmo Riley (1997), "Modelling the Components of the Brand", European Journal of Marketing, Vol. 32, Nos. 11/12, pp. $1074-1090$

Cotton, Nancy (1980), Women Playwrights in England c.1363-1750. Lewisburg: Bucknell University Press.

Davies, Gary (1998), "Retail Brands and the Theft of Identity", International Journal of Retail and Distribution Management. Vol. 26, No.4, pp. 140-146.

Davis, Herbert, ed. (1978), Pope: Poetical Works, Oxford: Oxford University Press. Day, George S., Allan D.Shocker, and Rajendra K. Srivastava (1979), “Customer Oriented Approaches to Identifying Product-Markets", Journal of Marketing, Vol. 43 (Fall). pp. 8-19. 
Defoe, Daniel (1987) The Complete English Tradesman, Gloucester: Sutton Publishing

Defoe, Nathaniel [?](1741), The Life and Character of Mr Alderman Barber.

London: T. Cooper.

Dickenson, Paul (2001), It's Not About Size. London:Virgin Publishing.

Doherty, Francis (1992), The Anodyne Necklace: A study in eighteenth-century advertising methods. London: Mellen.

Duffy, Maureen (1977), The Passionate Shepherdess: Aphra Behn 1640-89. London: Jonathon Cape.

Duncombe, John (1981) The Feminiad, intro. Jocelyn Harris. Los Angeles: William Andrews Clark Memorial Library, Publication No. 207.

Enright, Michael (2002) “Marketing and Conflicting Dates for its Emergence:

Hotchkiss, Bartels, the 'Fifties School' and Alternative Accounts", Journal of Marketing Management, Vol. No. pp.

Gildon, Charles (1696), The Histories and Novels of the late Ingenious Mrs. Behn ... Together with the Life and Memoirs of Mrs. Behn. London: S. Briscoe

--- (1702), A Comparison Between the Two Stages London: n.p.

Graeff, Timothy, R. (1996), "Using promotional messages to manage the effects of brand and self-image on brand evaluations", Journal of Consumer Marketing, Vol. 13, No. 3, pp. 4-18.

Hobby, Elaine (1988), Virtue of necessity: English women's writing, 1649-1688 London: Virago.

Elliott, Richard and Kritsadarat Wattanasuran (1998), “Brands as Symbolic Resources for Construction of Identity”, International Journal of Advertising, Vol. 17, No.2. [Anon.] Examiner, 12 April, 1714. 
---- 14 June 1711.

Feather, John "The Book Trade in Politics: The Making of the Copyright Act of 1710”, Publishing History, Vol. 19 (1980), pp. 19-44.

Fillis, Ian (2002) 'Creativity, Marketing and the Arts Organisation: What can the Artist offer? ', International Journal of Non-profit and Voluntary Sector Marketing, Vol. 7, No. 2, pp. 131-145

Fournier Susan (1998) "Consumers and their brands: developing relationship theory in consumer research”, Journal of Consumer Research, Vol. 24 No. 4, pp. 343-74 Gallagher, Catherine (1994), Nobody's story: the vanishing acts of women writers in the marketplace, Berkley, Los Angeles: University of California Press.

Grace, Debra and Aron O'Cass (2002) "Brand Associations: looking through the eye of the beholder", Qualitative Market Research, Vol. 5, No. 2.

Gwinner, Kevin (1997), “A Model of image creation and image transfer in event sponsorship", International Marketing Review, Vol. 14, No. 3, pp. 145-158

Halsband, Robert ed. (1965), The Complete Letters of Lady Mary Wortley Montague. 3 vols. Oxford: Clarendon.

Hammond, Brean S. (1997), Professional Imaginative Writing in England, 16701740: 'Hackney for Bread', Oxford: Clarendon.

Harvard Business Review eds. (1999), “The Logic of Product Line Extension”, Harvard Business Review on Brand Management. Boston, Mass: Harvard Business School Press.

Hearne, Mary (1718), The Lover's Week. London: [n.p.]

Heath, Stephen ed. (1977), Roland Barthes, Image-Music-Texts. London: Fontana/Collins. 
Herberg, Paul and John Milewicz (1995) "The relationship of reputation and credibility to brand success", Journal of Consumer Marketing, Vol.12, No. 4, pp. 5-10 Herman, Ruth (2003), The Business of a Woman. Delaware: University of Delaware Press.

Holmes, Geoffrey (1967), British Politics in the Age of Anne, London: MacMillan. Jamal, Ahmad and Mark M.H. Goode (2001), "Consumers and Brands: A study of the impact of self-image congruence on brand preference and satisfaction”, Vol. 19, No. 7, pp. 482-492.

Jones, Colin (1996) “The Great Chain of Buying: Medical Advertisement, The Bourgeois Sphere, and The Origins of the French Revolution", The American Historical Review, Vol. 101, No. 1, pp. 13-40

Keller, Kevin Lane (1998), Strategic Brand Management. New Jersey: Prentice Hall. King, John (1990), “Queen Elizabeth I: Representations of the Virgin Queen”, Renaissance Quarterly, No. 43, Vol. 1, pp. 30-74.

Koehn, Nancy F. (2001), Brand New: How Entrepreneurs Earned Consumers' Trust from Wedgwood to Dell. Boston, Mass: Harvard Business School Press.

Kohli, Chiranjeev (1997), Journal of Consumer Marketing, 14, 3, 206-219

Kropf, C.R. (1974-5), "Libel and Satire in the Eighteenth Century', Eighteenth-

Century Studies, Vol. 8, pp. 153-168

Labio, Catherine (1998), "What's in Fashion Vent: Behn, La Fayette and the Market for Novels and Novelty", Journal of Medieval and Early Modern Studies. Vol. 28, pp. 119-139.

Langbaine, G. [and Charles Gildon] (1712), The Lives and Characters of the English Poets, London: Tho. Leigh, William Turner. 
Lock, Andrew and Phil Harris (1996), “Political Marketing: Vive La Difference!”, European Journal of Marketing, Vol. 30, pp. 10/11

Luttrell, Narcissus (1857), A Brief Relation of State Affairs from September 1678 to April 1714. 6 vols. Oxford.

Manley, Delarivier (1696), Letters Writen by Mrs Manley. London: RB.

--- (1696) The Royal Mischief. London: n.p.

---- (1709), Memoirs from the New Atalantis. London: John Morphew.

---- (1700), The Nine Muses. London: Richard Bassett.

---- (1709), An Heroick Essay. London: A. Baldwin

----(1714), The History of Rivella. London: E. Curll

Mathias, Peter (1979), The Transformation of England: Essays in the economic and social history of England in the eighteenth century. London: Methuen.

McKendrick, Neil, John Brewer and J.H. Plumb (1982) The Birth of a Consumer Society: The Commercialisation of Eighteenth Century England, London: Europa Publications.

Meenaghan, Tony (1995), "The Role of Advertising in Brand Image Development”, Journal of Product and Brand Management, 4, 4 pp. 23-34.

Morgan, Fidelis (1986), A Woman of No Character. London: Faber and Faber.

--- (1981), The Female Wits: Women Playwrights on the London Stage, 1660-1720, London: Virago.

Myers, Robin and Michael Harris, eds. (1981), Development of the English Book Trade 1700-1899. Oxford: Oxford Polytechnic Press.

Plummer, Joseph T., (1986), “How Personality makes a Difference”, Journal of Advertising Research, (Feb-March). 
Porter, Roy (2000), Enlightenment: Britain and the Creation of the Modern World.

London: Penguin Books.

Porter, Roy (2001), Quacks, Fakes and Charlatans in English Medicine. Stroud:

Tempus Publishing.

Rivers, Isobel (1982), Books and their Readers in Eighteenth Century England.

Leicester: Leicester University Press.

Schroeder, J.E. (2000), "Manet, Klein and the Strategic Use of Scandal”, in Imagining Marketing: Art Aesthetics and the Avant Garde. eds. Stephen Brown and Anthony Patterson, London: Routledge.

Speck, W.R. (1998), Literature and Society in Eighteenth Century England. London: Longman.

Stationers Hall Records. Vol. I, BL, M985/6, f. 21; Volume II, BL, M985/6, f. 86, 23 November 1710.

Strauss, Ralph (1970), The Unspeakable Curll. New York: Augustus M. Kelley.

Sutherland, James R., (1934-35), “The Circulation of Newspapers and Literary

Periodicals 1700-30", The Library, Fourth Series, 15, pp. 110-124.

Tann, Jennifer (1977), “Advertising History and the Business Historian”, Journal of Advertising History

Turner, Cheryl (1992) Living by the Pen: Women Writers in the eighteenth century London: Routledge.

The Rival Dutchess: Or Court Incendiary (London: n.p., 1708).

Smith, Gareth (2001) The 2001 General Election: Factors Influencing the Brand Image of Political Parties and the Their Leaders. Journal of Marketing Management, Vol. 17, pp. 989-1006

Stearns, Peter N. (1997) The Journal of Modern History, Vol. 69, No. 1, pp. 102-117 
Street, John (1993) 'Musicologists, sociologists and Madonna', The European Journal of Social Sciences, Vol. 6, No. 3, p. 277.

Thompson, Craig J. (2000), "Going out in a blaze of glory”, in Imagining Marketing: Art Aesthetics and the Avant Garde. eds. Stephen Brown and Anthony Patterson, London: Routledge.

Till, Brian (1998), "Using celebrity endorsers effectively: lessons from associative learning”, Journal of Product and Brand Management, Vol. 7, No. 5, pp. 400-409

Todd, Janet (1988), "Life after Sex: the fictional autobiography of Delarivier Manley”, Women's Studies, No. 13, pp. 43-55.

Tompkins, J.M.S. (1969), The Popular Novel in England: 1770- 1800. London: Methuen.

Treadwell, Michael (1980), "London Printers and Printing Houses in 1705".

Publishing History, No. 7, p.7.

Urde, Mats (1999), "Brand Orientation”, Journal of Marketing Management, 15, 1-3

p. 122.

De Vries, Jan (1994) 'The Industrial Revolution and the Industrious Revolution', The Journal of Economic History, Vol. 54, No. 2, pp. 249-270.

Weatherill, Lorna (1988) Consumer Behaviour and Material Culture in Britain 16601760. London: Routledge.

Wood, Lisa (2000), "Brands and brand equity: definition and management", Management Decision, Nos. 38/9, pp. 662-669.

Manuscripts

HMC Downshire, Rev. Ralph Bridges to Sir William Trumbull, 11 November 1709. Vol. I, pt. 2, p. 883 